\title{
A Study of College Students' Autonomous English Listening Ability
}

\author{
YAN Yi-bo \\ Heze University, Heze, China
}

\begin{abstract}
Based on the data got from questionnaire in which 75 college students from Heze University participated, the present study aims to explore the current situation of college students' autonomous listening ability, its gender difference and the correlation between autonomous listening ability and CET-4 listening achievement. The results indicate that the autonomous listening ability for college students is at the medium level with a great individual difference and there's a vast space to be promoted. Moreover, there's no significant gender difference in autonomous listening ability for college students and there's significant positive correlation between autonomous listening ability and CET-4 Listening achievement, especially the dimension of Application of Strategies. Thus, a conclusion can be drawn that in English listening teaching, teachers should change their teaching model and strengthen the application of network teaching; in English listening learning, English learners should promote their ability of using strategies in English listening in order to improve their autonomous learning ability.
\end{abstract}

Keywords: autonomous listening learning, gender difference, correlation

\section{Introduction}

"Autonomous learning" is a concept dated from education philosophy. At the sixties of the 20th century, as the development of cognitive psychology and humanistic psychology, it comes into being. In 1981, Holec proposed the concept of "autonomy" in foreign language teaching. Studies on autonomous listening are branches of autonomous learning studies, and the combination study of autonomy and listening began in the prosperous stage which was mentioned by GAO Ji-li in 2006. Moreover, the learners' autonomous listening ability is unsatisfactory due to some facts. Hence, it is necessary for us to refine autonomous learning to a more detailed field-English listening.

By analyzing the data collected from questionnaire, the present thesis aims to explore the current situation of college students' autonomous listening ability, its gender difference, and the correlation between autonomous listening ability and CET-4 listening achievement, which has a certain theoretical and practical significance for college English listening teaching and learning.

Having defined "autonomous learning", scholars began to study the factors that influenced autonomous learning one after another. Cotterall (1995) analyzed the learners' beliefs towards autonomous learning through a questionnaire, and six factors were obtained, namely teacher's role, the effects of feedback, and so on. LI Kun and YU Li-ming (2008) made a survey study of 186 freshmen. The results indicate that the intrinsic and extrinsic motivation, self-efficacy and achievement attribution shows significant positive correlation with their

YAN Yi-bo, lecturer, M.A., Foreign Language Department, Heze University. 
autonomous learning behaviors and among which the most important one is self-efficacy, the second motivation, and the third achievement attribution. Ho and Crookall (1995) discussed the impacts on autonomous learning from cultural factors. However, Littlewood (1999) considered that it was not the fact that autonomous learning was unsuitable to implement in East culture. Besides, he proposed some suggestions for how to promote autonomous learning under East culture.

\section{Research Methodology}

\section{Subjects}

Random cluster sampling method was used in the present study to select a total of 80 non-English majors from Heze University to participate in the completion of the questionnaire.

\section{Instruments}

The investigating instruments employed in the research included a questionnaire and CET-4 (College English Test Band 4) listening score, which will be explained in details below.

\section{Questionnaire}

The questionnaires included two parts: personal information and Chinese version of Listening Autonomous Learning Scale. The scale was designed with reference to Rubin's How to Be a More Successful Language Learner (2004), Gardner and Miller's Establishing Self-access From Theory to Practice (2002) and Benson's Autonomy in Language Learning (2005). It consisted of six parts like motivations, learning material, management of autonomous listening, application of strategies, self-assessment, and autonomous listening after class. The scale is scored on a five-point scale and the subjects' responses to the items are assigned values of one, two, three, four, and five according to their daily listening learning. Specifically, one stands for "never or almost never true of me"; two stands for "usually not true of me"; three stands for "somewhat true of me"; four stands for "usually true of me"; and five stands for "always or almost always true of me". The theoretical score of the scale ranges from 35 to 175 , which aims to measure the listening autonomous learning situation.

The standard which Oxford used for the reading strategies were adopted in the research. That was, if the average score was above 3.5, it meant the subjects had a high autonomous listening ability. If it was below 2.4, they had a low autonomous listening ability. If it was between 2.5 and 3.4, they had a moderate autonomous listening ability.

\section{CET-4 Listening Score}

The CET-4 listening sore used in the present study was obtained from the CET-4 held on December 20, 2014. CET-4 is a large-scale standardized test administered by the National College English Testing Committee on behalf of the Chinese Ministry of Education. It has been reported to have very high reliability and validity.

\section{Data Collection and Analysis}

All the English teachers who take part in the research have had a strict training and were unified the guiding words before the research. All the teachers implemented the questionnaires in their own class for about 20 minutes in March 2015. Related teachers fill the time, place, and questionnaires of distribution and recovery at once after the research. The recovery of the questionnaires is $100 \%$. After rejecting incomplete and obvious response tendency questionnaires, we got 75 effective questionnaires. The subjects' responses to each item of the questionnaire were entered into computer. The data were processed by using the Statistical Package for the 
Social Sciences (SPSS), which was used to analyze the data collected from the study.

\section{Results and Discussion}

This part presents the results and discussion of three research questions in the present study by analyzing the data collected from questionnaire survey. Firstly, the general situation of college students' autonomous listening ability will be shown. The second section will explore the gender difference in college students' autonomous listening ability and moreover, the third section analyses the results and discussion on the correlation between autonomous listening ability and CET-4 listening achievement.

\section{General Situation of College Students' Autonomous Listening Ability}

For the sake of dealing with the first research question of present study of what is the general situation about college students' autonomous listening ability, descriptive analysis was performed in this section.

Situation of overall scale. The results from descriptive analysis of overall Autonomous Listening Ability Scale (ALAS) were reported in Table 1, from which we can learn the general situation of learner's autonomous listening ability.

Table 1

Descriptive Statistics of Overall Scale

\begin{tabular}{lllll}
\hline $\mathrm{N}$ & Minimum & Maximum & Mean & Std. Deviation \\
\hline 75 & 49 & 138 & 88.24 & 16.247 \\
\hline
\end{tabular}

As the Table 1 shows the questionnaire items are calculated from the following five aspects: number, minimum, maximum, mean, and standard deviation.

In the present study, the ALAS scores for the whole samples range from 49 to 138, with a mean of 88.24 and standard deviation of 16.247. Based on the finding above, it can be concluded that college English learner' autonomous listening ability is at the medium level. In addition, the standard deviation of 16.247 shows that there is significant individual difference in college English learners' autonomous listening ability. It is easy to explain the results above that to different language learners, their listening motivation, learning materials, autonomous listening management, listening strategies, self-assessment, and Autonomous Listening Sense are totally different, which result in the natural great variety in learners' autonomous listening ability.

According to the data collected, we can draw the conclusion that there is still a large space for most of the college students to improve their autonomous listening ability. They potentially can be autonomous if given the right guidance and learning situation. So it is important to provide learner training for students, and reform the current teaching mode.

Situation of specific items. Obviously, the description above gave us a brief overview of situation of college English learners' autonomous listening ability. However, in order to get more specific situation, some specific items of the scale should be explored next. The related descriptive dates are showed in Table 2.

Table 2

Descriptive Statistics for Each Dimension and Item

\begin{tabular}{llllll}
\hline Dimension & Mean & Std. Deviation & Item & Mean & Std. Deviation \\
\hline \multirow{2}{*}{ Learning Motivation } & & & 1 & 2.08 & 1.06 \\
& 0.50 & 3.396 & 2 & 3.10 & 1.25 \\
\hline
\end{tabular}




\begin{tabular}{|c|c|c|c|c|c|}
\hline & & & 4 & 3.89 & 1.19 \\
\hline & & & 5 & 3.53 & 1.14 \\
\hline \multirow{5}{*}{ Learning Materials } & \multirow{5}{*}{0.47} & \multirow{5}{*}{3.550} & 6 & 2.84 & 1.15 \\
\hline & & & 7 & 2.66 & 1.00 \\
\hline & & & 8 & 3.69 & 1.13 \\
\hline & & & 9 & 2.44 & 1.10 \\
\hline & & & 10 & 2.53 & 1.16 \\
\hline \multirow{5}{*}{ Management of Autonomous Listening } & \multirow{5}{*}{0.37} & \multirow{5}{*}{3.896} & 11 & 2.32 & 1.04 \\
\hline & & & 12 & 2.00 & .90 \\
\hline & & & 13 & 2.08 & .95 \\
\hline & & & 14 & 2.29 & .95 \\
\hline & & & 15 & 2.41 & .97 \\
\hline \multirow{5}{*}{ Application of Strategies } & \multirow{5}{*}{0.40} & \multirow{5}{*}{3.680} & 16 & 2.36 & .93 \\
\hline & & & 17 & 2.53 & .93 \\
\hline & & & 18 & 2.81 & 1.06 \\
\hline & & & 19 & 2.16 & 1.02 \\
\hline & & & 20 & 2.38 & 1.03 \\
\hline \multirow{5}{*}{ Self-assessment } & \multirow{5}{*}{0.55} & \multirow{5}{*}{3.521} & 21 & 3.17 & 1.11 \\
\hline & & & 22 & 2.76 & 1.06 \\
\hline & & & 23 & 3.24 & 1.16 \\
\hline & & & 24 & 3.60 & .92 \\
\hline & & & 25 & 3.93 & 1.16 \\
\hline \multirow{5}{*}{ Autonomous Listening Sense } & \multirow{5}{*}{0.62} & \multirow{5}{*}{4.083} & 26 & 4.21 & 1.05 \\
\hline & & & 27 & 4.37 & 1.13 \\
\hline & & & 28 & 4.05 & 1.21 \\
\hline & & & 29 & 2.40 & 1.10 \\
\hline & & & 30 & 3.66 & 1.34 \\
\hline
\end{tabular}

As stated above, ALAS is composed of six dimensions: Learning Motivation, Learning Materials, Management of Autonomous Listening, Application of Strategies, Self-assessment, and Autonomous Listening Sense. The data from the descriptive analysis displays that the rank of these six dimensions from high to low is Autonomous Listening Sense $($ mean $=0.62)>$ Self-assessment $($ mean $=0.55)>$ Learning Motivation $($ mean $=$ $0.50)>$ Learning Materials (mean $=0.47)>$ Application of Strategies $($ mean $=0.40)>$ Management of Autonomous Listening (mean $=0.37$ ). The findings above suggest that most of the college students have been awarded the importance of autonomy in listening learning and they always evaluate their self-learning after class. However, they still have some difficulties in arranging the autonomous agenda and need some effective autonomous strategies badly.

As for the composing items (items 26-30) of Autonomous Listening Sense dimension, the samples got the highest mean score in item 27 (I surf the Internet at least once a week. Mean = 4.37), which suggests that for most college students, Internet has been one of popular means to learn language and get information. Moreover, the mean score for item 26 is also high (I think we should keep learning after class to improve our listening ability. Mean = 4.21), which indicates that students have realized their duty and obligations in English listening to get a better grade about it. To sum up, those two items suggest that Internet as an important medium plays an indispensable role and students can have autonomous listening in web autonomous environment.

As for the composing items (items 11-15) of Management of Autonomous Listening dimension, the samples got the lowest mean score in item 12 (I often do some listening study after school. Mean $=2.00$ ), 
which indicates that students seldom practice their listening ability after school and they primarily acquire the knowledge and experience in class. In other word, they lack the ability of managing their listening learning time; most of them are uncertain about their allocation of learning time. Based on the analysis above, we can conclude that the learners are lack of initiative in listening learning and do not regard themselves as the master of learning, so the key point is to cultivate their ability to take charge of their listening learning.

\section{Gender Difference in College Students' Autonomous Listening Ability}

For the sake of exploring the second research question in the present study of whether there is gender difference in college English learners' autonomous listening ability, both descriptive analysis and independent samples (Table 3) are used in this part.

The result got from descriptive statistics and Independent Sample T-Test for Gender Difference in autonomous listening were reported in Table 3, from which we can learn whether there is gender difference in college English learners' autonomous listening ability .

As the data show, the male college students got higher score $(M=89.08)$ in the scale than their counterparts $(M=87.84)$ which indicates that the male learners do better than the female learners in English autonomous listening. However, there is no significant gender difference in college students' autonomous listening ability as a whole $(\mathrm{p}=0.760>0.05)$.

Table 3

Descriptive Statistics and Independent Sample T-Test for Gender Difference in College English Learners' Autonomous Listening Ability

\begin{tabular}{|c|c|c|c|c|c|c|}
\hline Dimension & Gender & $\mathrm{N}$ & Mean & Std. Deviation & $\mathrm{t}$ & $\mathrm{p}$ \\
\hline \multirow{2}{*}{ Autonomous Listening Ability } & Male & 24 & 89.08 & 19.700 & \multirow{2}{*}{.306} & \multirow{2}{*}{.760} \\
\hline & Female & 51 & 87.84 & 14.548 & & \\
\hline \multirow{2}{*}{ Listening Motivation } & Male & 24 & 15.25 & 4.542 & \multirow{2}{*}{-.075} & \multirow{2}{*}{.940} \\
\hline & Female & 51 & 15.31 & 2.753 & & \\
\hline \multirow{2}{*}{ Learning Materials } & Male & 24 & 14.04 & 4.102 & \multirow{2}{*}{-.216} & \multirow{2}{*}{.827} \\
\hline & Female & 51 & 14.24 & 3.302 & & \\
\hline \multirow{2}{*}{ Management of Autonomous Listening } & Male & 24 & 11.67 & 4.556 & \multirow{2}{*}{.852} & \multirow{2}{*}{.397} \\
\hline & Female & 51 & 10.84 & 3.563 & & \\
\hline \multirow{2}{*}{ Application of Strategies } & Male & 24 & 13.00 & 4.501 & \multirow{2}{*}{1.209} & \multirow{2}{*}{.231} \\
\hline & Female & 51 & 11.90 & 3.214 & & \\
\hline \multirow{2}{*}{ Self-assessment } & Male & 24 & 16.71 & 4.016 & \multirow{2}{*}{.003} & \multirow{2}{*}{.998} \\
\hline & Female & 51 & 16.71 & 3.306 & & \\
\hline \multirow{2}{*}{ Autonomous Listening Sense } & Male & 24 & 18.42 & 4.605 & \multirow{2}{*}{-.420} & \multirow{2}{*}{.676} \\
\hline & Female & 51 & 18.84 & 3.854 & & \\
\hline
\end{tabular}

As to the specific dimensions of the scale, there is also no significant gender difference, which indicates that male college students are not significantly higher or lower than their counterparts. Therefore, in the process of listening teaching process, there is no necessity to take gender element in teaching plan consideration. In addition, there are some details we cannot ignore. Female students have much more motivation and sense in autonomous listening compared with their counterparts; what is more, they are making use of available learning resources to facilitate autonomous learning. For male students, they are better at the learning field related with rational thought such as strategies or management. 


\section{Correlation Between College Students' Autonomous Listening Ability and CET-4 Listening Achievement}

The third research question in the present study aims to explore the correlation between College English Learners' Autonomous Listening Ability and CET-4 listening score, in which Pearson correlation analysis is conducted.

Table 4

Correlation Between Autonomous Listening Ability and CET-4 Listening Achievement

\begin{tabular}{lllllllll}
\hline & & ALA & LM & LMs & MOAL & AOS & S-a & A LS \\
\hline \multirow{2}{*}{ CET 4 listening } & Pearson correlation & 1 & $.748^{* *}$ & $.730^{* *}$ & $.776^{* *}$ & $.811^{* *}$ & $.669^{* *}$ & $.675\left(^{* *}\right)$ \\
Achievement & Sig.(2-tailed) & .000 & .000 & .000 & .000 & .000 & .000 & .000 \\
& $\mathrm{~N}$ & 75 & 75 & 75 & 75 & 75 & 75 & 75 \\
\hline
\end{tabular}

Note. ${ }^{* *}$ Correlation is significant at the 0.01 level (2-tailed).

As is shown in Table 4, there is a significant positive correlation between autonomous listening ability and CET-4 listening achievement $(\mathrm{p}=.000<.01)$. That is to say, the higher the autonomous listening ability college learners have, the higher their CET-4 listening achievement is. In other words, learner's autonomous learning ability has a positive impact on their listening achievement. Therefore, autonomous learning ability is very important for students to have a good performance in their English listening process.

As for the composing dimensions of the scale, there is also a significant positive correlation between each dimension and CET-4 Listening achievement, which suggests that in order to improve learner's listening competence, every aspect cannot be omitted. Moreover, among the six specific dimensions, the highest correlation coefficient comes from Application of Strategies dimension, which indicates that compared with other elements, mastering a range of useful listening strategies plays the most important role in improving autonomous listening ability. Students should learn to use effective and suitable listening strategies in their listening study process. They should try to plan, monitor, and regulate their listening learning, and they also should have a sense that listening strategies should be strengthened so that they can apply them to listening practice consciously. Secondly, students should be a master of their listening study and they should make full use of their spare time to practice their English listening skill. Moreover, clear goals and reasonable plans are also necessary to students' autonomous listening ability.

\section{Implications on Listening Teaching and Learning}

Based on the analysis on findings of this study, there are some suggestions to promote college English learners' autonomous listening ability.

\section{Implications on Listening Teaching}

First of all, in view of the lower using frequency of selecting listening strategies use among students, it is indicated that teachers are supposed to stress the importance of using strategies in listening learning, and introduce various categories of listening strategies in listening class, and then design strategies training which can cater to the students' taste. Finally, teachers ought to select suitable strategies based on different learning materials.

Secondly, learning environment is also a very essential element to promote the autonomous learning.

\footnotetext{
${ }^{1}$ ALA - Autonomous Listening Ability; LM-Listening Motivation; LMs - Learning Materials; AOS_Application of Strategies; S-a-Self-assessment; ALS - Autonomous Listening Sense; MOAL—Management of Autonomous Listening.
} 
Teachers should create a listening learning atmosphere where learner autonomy is favored, such as introducing large amount of suitable English original songs, TV shows, and movies, which are beneficial for the student to make contact and be more familiar with the original language; meanwhile, students will be much more interested in conducting autonomous learning. Hence, the language teachers need to cultivate the learners' independent ability and give students more positive support.

Moreover, based on students' autonomous listening situation, online education should be put forward and paid more and more attention. Last but not least, as a guide, teachers have to teach students in accordance with their aptitude and add some strategies instruction courses into their normal class as well as some integrate strategies training and give the learners time to think independently, but also offer them chance to present their idea and receive reflection from peer learners. Teachers should let their students know the important of teamwork.

\section{Implications on Listening Learning}

At the first place, the learners should try to find some effective listening strategies according to the different learning tasks. It is suggested that teachers should firstly introduce they are required to set up a realistic goal or plan for learning so that they can make good use of their time.

Secondly, learners should combine individual thinking with group cooperation. This method can not only give the learners time to think independently, but also offer them chance to present their idea and receive reflection from peer learners.

Thirdly, students should strengthen self-controlling consciousness by means of self-encouragement and stage assessment. Language learning is a long road to the mountain with countless ups and downs, which requires consistent motivation. Solid confidence and timely evaluation are the real origin of vigorous motivation.

Lastly, students are supposed to transfer autonomous learning motivation into action. In other words, they had better combine consciousness and action in order to perfect autonomous listening skills.

All in all, the present research has shed some lights on autonomous English listening learning, which can be helpful to both English's teaching and learning. Foreign language autonomous learning plays a crucial role in language acquisition; therefore, it deserves more attention and further research in the future.

\section{Conclusion}

Based on the statistical analysis of the results and the discussions, the major findings got from this thesis can be summarized as follows:

(1) The autonomous listening ability for college students is at the medium level with a great individual difference and there is a vast space to be promoted. To be specific, college students have been awarded the importance of autonomy in listening learning and they always evaluate their self-learning after class. However, they still have some difficulties in arranging the autonomous agenda and need some effective autonomous strategies badly;

(2) In addition, there is no significant gender difference in college students' autonomous listening ability;

(3) Last but not least, there is a significant positive correlation between autonomous listening ability and CET-4 listening achievement, especially the dimension of Application of Strategies.

Although we have drawn some useful conclusions from this study as we have mentioned above, there are 
also some limitations. First, the subjects chosen in the present research were only confined to English major students of Heze University, which may have great impact on the reliability and validity of the research statistics. Further empirical researchers are needed to investigate the English learners of various types and of different periods to have a more detailed data. Secondly, quantitative research method was only used in the present study that there was no support from the qualitative data.

All in all, the present research has shed some lights on autonomous English listening learning, which can be helpful to both English's teaching and learning. Foreign language autonomous learning plays a crucial role in language acquisition; therefore, it deserves more attention and further research in the future.

\section{References}

Benson, P. (1997). Autonomy crud independence in language learning (pp. 18-34). New York: Addison Wesley Longman.

Benson, P. (2005). Teaching and researching autonomy in language learning. Beijing: Foreign Language Teaching and Research Press.

Boud, D. (1988). Developing student autonomy in learning. London: Kogan Page.

Cotterall, S. (1995). Developing a course strategy for learner autonomy. ELT Journal, 3, 219-227.

Ho, J., \& Crookall, D. (1995). Breaking with Chinese cultural traditions: Learner autonomy in English language teaching. Pergamon, 2, 235-243.

Little, D. (1991). Learner autonomy definitions, issues and problems (pp. 3-5). Dublin: Authentik.

Littlewood, W. T. (1999). Defining and developing autonomy in East Asian context. Applied Linguistics, 1, 71-94.

Mori, S. (2002). Redefining motivation to read in a foreign language. Reading in a Foreign Language, 2, 91-110.

Oxford, R. L., \& Burry-stock, J. A. (1995). Assessing the use of language learning strategies worldwide with the ESL/EFL version of the strategy inventory for language learning (SILL). System, 4, 1-23.

Wenden, A. L. (1986). What do second-language learners know about their language learning. Applied Linguistics, 2, $186-201$. 